\title{
DIPLOMASI PUBLIK INDONESIA MELALUI BALI DEMOCRACY FORUM SEBAGAI BAGIAN DARI KEBIJAKAN POLITIK LUAR NEGERI INDONESIA
}

\author{
Yolla Anggraeni, Indrawati \\ Universitas 17 Agustus 1945 Jakarta \\ yeollanggraeni@gmail.com, in.indrawati17@gmail.com
}

\begin{abstract}
ABSTRAK
Sebagai negara demokrasi terbesar ketiga di dunia, negara dengan jumlah penduduk muslim terbesar, pengalaman Indonesia mempertahankan demokrasi dan keberhasilan Indonesia untuk bangkit setelah krisis adalah modal yang berharga yang harus dibagikan kepada negara lain. Demokrasi menjadi ikon dan salah satu asset diplomasi Indonesia, khususnya dalam diplomasi publik, disamping islam moderat, ekonomi progresif, masyarakat plural dan budaya beragam yang dimiliki Indonesia. Penerapan diplomasi publik sangat ditentukan dari kesiapan Indonesia terhadap sistem demokrasi. Pada masa kepemimpinan Susilo Bambang Yudhoyono demokrasi dan penegakan HAM merupakan bagian dari kebijakan politik luar negeri. Kebijakan ini didasari pada pemahaman Indonesia terhadap nilai-nilai kemanusiaan. Maka dari itu gagasan besar untuk menyelenggarakan forum demokrasi dalam rangka mendorong pengembangan demokrasi dan juga mempromosikan demokrasi di kawasan Asia-Pasifik dan negara-negara diluar kawasan yakni melalui Bali Democracy Forum.
\end{abstract}

Kata Kunci: Bali Democracy Forum, Diplomasi Publik, Politik Luar Negeri

\section{ABSTRACT}

As the third largest democracy in the world, a country with the largest Muslim population, experience of Indonesia of maintaining democracy and success of Indonesia to rise after the crisis is valuable capital that must be distributed to other countries. Democracy has become an icon and one of diplomacy assets of Indonesia, especially in public diplomacy, besides moderate Islam, progressive economics, plural society and diverse cultures that Indonesia has. The application of public diplomacy is largely determined by readiness of Indonesia for a democratic system. During leadership of Susilo Bambang Yudhoyono democracy and human rights enforcement were part of foreign policy. This policy is based on Indonesia's understanding of Indonesia of human values. Therefore the big idea is to hold a democratic forum in order to encourage the development of democracy and also promote democracy in the Asia-Pacific region and countries outside the region, namely through the Bali Democracy Forum.

Keywords: Bali Democracy Forum, Public Diplomacy, Foreign Policy. 


\section{PENDAHULUAN}

Setiap negara memiliki pandangan yang berbeda mengenai pelaksanaan demokrasi, tergantung dari sistem politik yang anutnya. Pandangan tersebut kemudian menjadi suatu indikator untuk mengukur pelaksanaan demokrasi di suatu negara sebagai upaya pencarian jati diri bangsa (Gramae, 2003). Indonesia melihat bahwa kawasan Asia dan Pasifik saat ini masih tertinggal dibandingkan dengan kawasan lain dalam berbicara mengenai demokrasi dan hak asasi manusia dan lebih berbicara tentang pembangunan ekonomi. Bagi pemerintahan saat itu pembangunan ekonomi adalah yang terpenting, sehingga pembangunan politik terlantarkan, padahal keduanya harus berjalan secara beriringan. Nilai demokrasi belakangan ini menjadi penting, seiring berkembangnya kesadaran akan kebebasan politik. Namun tidak semua negara bisa dengan mudah mengadopsi nilai demokrasi, khususnya negara-negara yang menganut sistem autokrasi dan baru memulai belajar nilai demokrasi. Bagi Indonesia demokrasi penting untuk dapat memajukan pembangunan dan meningkatkan kesejahteraan masyarakat, karena demokrasi merupakan alat untuk mencapai keadilan sosial, perdamaian dan kemakmuran bangsa. Setelah Reformasi 1998, demokrasi Indonesia berkembang pesat dan membawa Indonesia menjadi negara demokrasi ketiga terbesar di dunia setelah Amerika Serikat dan India. Dari 53 negara hanya 26\% yang dikategorikan sudah menganut paham demokrasi, selanjutnya 36\% dari jumlah negara di kawasan Asia-Pasifik masih setengah demokratis (Saubani, 2016).

Bagian yang tak terpisahkan dari setiap kebijakan kementerian Indonesia, khususnya pada kebijakan terkait kawasan Asia yaitu adalah mempromosikan demokrasi Indonesia. Dengan begitu keaktifan Indonesia dalam mempromosikan demokrasi di kawasan Asia Pasifik dapat mencapai kepentingan nasional Indonesia yakni memajukan kepemimpinan Indonesia dipanggung regional dan global. Konsep dari Bali Democracy Forum menggunakan demokrasi Pancasila yang mengutamakan keseragaman dan kesatuan. Sesuai dengan filosofi bangsa yang harus tercerminkan dalam setiap kebijakan luar negeri Indonesia. Di bawah kepemimpinan Presiden Susilo Bambang Yudhoyono, Bali Democracy Forum (BDF) telah diresmikan dan berkembang secara signifikan sejak dicetuskan pada tahun 2008. Bali Democracy Forum merupakan forum tahunan antar pemerintah yang inklusif dan terbuka. Forum ini diselenggarakan pertama kali pada 10 Desember - 11 Desember 2008 dan akan terus 
diselenggarakan setiap tahunnya. Maka dari itu gagasan besar untuk menyelenggarakan forum demokrasi dalam rangka mendorong pengembangan demokrasi dan juga mempromosikan demokrasi di kawasan Asia-Pasifik dan negara-negara di luar kawasan yakni melalui Bali Democracy Forum. Hal ini kemudian menjadi inisiatif yang baik untuk mendorong kuatnya demokrasi yang tidak dipaksakan, tetapi juga tumbuh dan berkembang dari kekuatan dan kemampuan dari dalam. Dalam hal ini soft power menjadi perangkat penting dalam pelaksanaan diplomasi publik. Indonesia sebagai suatu negara yang menerapkan demokrasi dengan baik dapat memberikan keuntungan tersendiri bagi Indonesia serta dapat menumbuhkan kepercayaan dari negara lain mengenai potensi dan prestasi bagi negara tersebut.

\section{KERANGKA TEORITIS}

\section{DIPLOMASI PUBLIK}

Diplomasi publik dapat diartikan sebagai sebuah langkah yang tujuannya mempengaruhi lingkup global atau negara lain untuk mencapai kepentingan nasional negaranya sendiri. Kemudian langkah selanjutnya yaitu dengan membentuk hubungan kerjasama yang saling berkaitan sehingga bisa mempermudah negara tersebut dalam menjalankan kebijakan luar negerinya. Secara singkat diplomasi publik adalah sebuah propaganda, branding negara, dan mendorong pertukaran budaya. Sebenarnya diplomasi masih dapat diperluas ke dalam banyak hal, di Indonesia praktik diplomasi publik ditujukan kepada internasional dan juga kawasan domestik. Diplomasi publik banyak dipengaruhi oleh kondisi politik internasional, kondisi internal negara, dan juga isu-isu politik baik dalam maupun luar negeri.

Menurut Leonard, ada empat tujuan diplomasi publik di abad 21, yaitu (Leonard M. , 2002):

1. Meningkatkan keakraban serta membuat masyarakat berfikir dan mengubah image persepsi mereka tentang negara, serta meningkatkan pengetahuan masyarakat mengenai negara tersebut. 
2. Meningkatkan apresiasi menghadirkan persepsi yang positif dengan membuat masyarakat melihat suatu isu dari perspektif negara tersebut.

3. Merangkul masyarakat dan mendorong masyarakat untuk melihat suatu negara sebagai tujuan yang menarik bagi pariwisata dan studi, membeli barang barang, maupun mengadopsi nilai-nilai negara tersebut.

4. Mempengaruhi sikap masyarakat dan meningkatkan dukungan masyarakat terhadap posisi negara tersebut.

Diplomasi publik dari sudut pandang tradisional berbasis pada aktivitas resmi, seperti pameran pertukaran budaya, seminar, promosi ekonomi, advokasi politik, dan lain sebagainnya. Hampir semua aktivitas disusun dan diatur oleh pemerintah. Namun sekarang, sebuah pemerintahan tidak bisa berdiri sendiri dalam menghadapi hubungan internasional yang semakin rumit. Mereka membutuhkan dukungan dari aktor yang lain yaitu aktor non negara. Hubungan antara diplomasi dan politik luar negeri erat kaitannya. Politik Luar Negeri mengalami dua tahapan dalam prosesnya, yaitu pada tataran pembuatan dan implementasi kebijakan. Diplomasi merupakan salah satu instrumen dimana keputusan atau kebijakan di implementasikan (White, 1997). Dalam pengertian yang luas diplomasi publik tidak hanya mneyangkut pada tataran implementasi, tapi juga proses pembuatan kebijakan. Hal ini terkait dengan fungsi dari diplomasi itu sendiri yang mneyangkut pengumpulan informasi, pemberian saran terhadap kebijakan, perwakilan, negosiasi, dan jasa-jasa konsuler (White, 1997).

Peranan diplomasi sebagai instrumen politik luar negeri semakin mengemuka. Philip Fiske de Gouveia mengindikasikan terdapat delapan prediksi mengenai masa depan diplomasi publik yakni sebagai berikut (Gouveia, 2005):

1. Mengedepankan soft power yang tidak didominasi oleh elit, tetapi lebih melibatkan lebih banyak publik.

2. Munculnya komunikasi yang bersifat agresif dan lebih kompetitif. Ketika semua negara mengkomunikasikan kebaikan-kebaikan negaranya dan apa yang bisa 
ditawarkan, maka informasi yang muncul menjadi bisa dan yang terjadi lebih agresif.

3. Menumbukan kerjasama, meskipun disatu sisi diplomasi publik menjadi agresif dan kompetitif.

4. Media global tidak lagi didominasi oleh media barat.

5. Diplomasi publik dilakukan didalam negeri harus seiring dengan diplomasi publik yang dilakukan diluar negeri.

6. Diplomasi publik tidak lagi otoritas pemerintah, tetapi diplomasi publik sering dilakukan oleh perusahaan-perusahaan swasta dan konsultan yang mengatasnamakan pemerintah.

7. Teknologi memiliki peranan dalam mempengaruhi pembuatan, pengukuran keberhasilan, dan evaluasi pelaksanaannya.

8. Diplomasi publik dan strategi komunikasi diperlukan untuk mengatasi permasalahan-permasalahan global.

Diplomasi publik juga dikenal dengan istilah 'second track diplomacy' yang secraa umum didefinisikan sebagai upaya-upaya diplomasi yang dilakukan oleh berbagai elemen non-pemerintah cera tidak resmi. Second track diplomacy bukan bertindak sebagai pengganti first track diplomacy, dengan kata lain upaya yang dilakukan second track diplomacy harus melancarkan jalan bagi negosiasi dan persetujuan dalam rangka first track diplomacy dengan cara mendorong para diplomat untuk memanfaatkan informasi penting yang diperoleh oleh pelaku second track diplomacy. Diplomasi publik menjadi upaya alternatif agara diplomasi berjalan dengan lebih efektif dan memberikan dampak yang lebih luas dan besar pada masyarakat internasional. keterlibatan publik ini dapat membuka jalan bagi negosiasi yang dilakukan oleh wakil-wakil pemerintah, sekaligus dapat memberikan masukan dan cara pandang yang berbeda dalam memandang suatu masalah (Pudjomartono, 2008).

\section{Politik Luar Negeri}


Politik luar negeri merupakan salah satu bidang kajian dalam studi Hubungan Internasional. Politik luar negeri merupakan suatu studi yang kompleks karena tidak hanya melibatkan aspek-aspek eksternal tetapi juga melibatkan aspek-aspek internal suatu negara (Rosenau, 1976). Negara sebagai aktor yang melakukan politik luar negeri tetap menjadi unit politik utama dalam sistem hubungan internasional, meskipun aktoraktor non-negara semakin memainkan peran pentingnya dalam hubungan internasional (Rosenau, 1976). Dalam proses pengambilan politik luar negeri suatu negara tergantung pada sistem politik dalam negeri di negara tersebut. Tetapi secara umum dalam sebuah negara, pelaksanaan politik luar negeri melibatkan semua pejabat dan badan administratif dalam suatu pemerintahan yang langsung ataupun tidak langsung turut menyiapkan pembuatan maupun pelaksanaan dari barbagai keputusan yang berkenaan dengan politik luar negeri. Snyder memberikan dua faktor utama yang mempengaruhi proses pengambilan keputusan yaitu faktor subyektif dan sumber-sumber potensial. Kebijakan luar negeri merupakan strategi atau rencana tindakan yang dibuat oleh para pembuat keputusan negara dalam menghadapi negara lain atau unit politik internasional lainnya, dan dikendalikan untuk mencapai tujuan nasional spesifik yang dituangkan dalam terminologi kepentingan nasional. Kebijakan luar negeri yang dijalankan oleh pemerintah suatu negara memang bertujuan untuk mencapai kepentingan nasional masyarakat yang diperintahnya meskipun kepentingan nasional suatu bangsa pada waktu itu ditentutakan oleh siapa yang berkuasa pada waktu itu. Untuk memenuhi kepentingan nasionalnya itu, negara-negara maupun aktor dari negara tersebut melakukan berbagai macam kerjasama diantaranya adalah kerjasama bilateral, trilateral, regional dan multilateral (Mas'ud, 1994).

Tujuan politik luar negeri dapat dikatakan sebagai citra mengenai keadaan dan kondisi di masa depan suatu negara dimana pemerintah melalui para perumus kebijaksanaan nasional mampu meluaskan pengaruhnya kepada negara-negara lain dengan mengubah atau mempertahankan tindakan negara lain. Ditinjau dari sifatnya, tujuan politik luar negeri dapat bersifat konkret dan abstrak. Sedangkan dilihat dari segi waktunya, tujuan politik luar negeri dapat bertahan lama dalam suatu periode waktu 
tertentu dan dapat pula bersifat sementara, berubah sesuai dengan kondisi waktu tertentu.

\section{Demokrasi}

Demokrasi adalah salah satu identitas nasional Indonesia sebagaimana tercermin dalam pasal-pasal konstitusi yang menyatakan bahwa Indonesia merupakan negara demokrasi dengan kedaulatan ditangan rakyat dan pelaksanaannya kemudian diatur dalam pasal-pasal konstitusi, UUD 1945. Dalam perkembangannya demokrasi di Indonesia telah berkembang jauh mengikuti dinamika zaman dengan dipengaruhi oleh faktor internal maupun faktor eksternal. Pasca kemerdekaannya pada tahun 1945, Indonesia yang telah berganti tampuk kepemimpinan tidak pernah meninggalkan retorika Indonesia sebagai negara demokrasi. Sejarah mencatat adanya dua rezim yang sangat berkuasa yang pernah memerintah Indonesia, kedua rezim tersebut adalah pemerintahan rezim Soekarno dan Rezim Soeharto. Kedua rezim tersebut mampu menguasai hampir seluruh aspek kehidupan dan membuat elemen-elemen masyarakat Indonesia, baik elemen ssosial maupun politik, tunduk pada kehendaknya (Manan, 2005).

\section{PEMBAHASAN}

Secara historis Bali Democracy Forum (BDF) merupakan forum diskusi tahunan antar pemerintah yang insklusif dan terbuka pada perkembangan demokrasi di kawasan Asia-Pasifik, yang bertujuan mempromosikan dan mendorong kerjasama regional dan internasional dalam bidang perdamaian dan demokrasi melalui dialog, saling bertukar pengalaman dan praktekpraktek mengenai demokrasi yang diterapkan diberbagai negara dengan berdasarkan pada prinsip kesetaraan, saling menghormati dan pengertian. Forum ini diikuti oleh perwakilan diberbagai negara-negara dikawasan Asia-Pasifik, baik kepala negara, menteri, tokoh-tokoh penting serta masyarakat internasional. Salah satu ciri khas Bali Democracy Forum dalam mempromosikan demokrasi adalah diadopsinya pendekatan inklusif, yaitu tidak adanya pembatasan keikutsertaan dalam forum pada negara-negara yang benar-benar telah legitimate 
sebagai negara demokrasi, tetapi juga negara-negara yang pada dasarnya masih menganut sistem politik otoritarianisme militer atau sipil, totalitarianism, monarki absolut, teokrasi, atau sistem satu partai tunggal. Pendekatan inklusif ini dimaksudkan agar negara-negara peserta tidak dieksklusi dan merasa nyaman dalam mengikuti percakapan tentang demokrasi dan saling tukar pengalaman mengenai praktik terbaik dalam demokrasi (Azra A. , 2012).

Bali Democracy Forum pertama kali dibentuk pada tahun 2008 oleh Presiden Susilo Bambang Yudhoyono yang mana pada kegiatan ini dinaungi oleh Kementerian Luar Negeri Indonesia. Pertemuan pada forum ini menjadi menarik karena turut serta melibatkan negaranegara yang masih dalam taraf memulai menerapkan prinsip demokrasi, maupun negara yang berkomitmen untuk menerapkan prinsip-prinsip demokrasi meskipun dianggap masih belum demokratis.

Pelaksanaan Bali Democracy Forum dinilai memiliki keunikan bukan hanya materi dalam forum tersebut tetapi pemilihan Bali sebagai tempat. Bali dengan keindahannya dan uniknya pulau yang mayoritas warganya beragama Hindu dinegara yang mayoritas Islam, yang kemudian hak tersebut dapat menarik wisatawan yang datang. Hal ini menjadi nilai tambah bagi Indonesia dengan menggabungkan pulau yang indah dengan konsep (dialog) serius mengenai demokrasi. Salah satu mengapa Indonesia mengadakan Bali Democracy Forum adalah ingin melakukan pendekatan yang berbeda (Nugraha, 2018).

\section{Perkembangan Demokrasi di Kawasan Asia Pasifik}

Sejarah mencatat demokrasi tumbuh dan berkembang cepat diberbagai kawasan dunia. Setelah reformasi 1998, demokrasi Indonesia tercatat sebagai salah satu negara dengan perkembangan demokrasi paling pesat di dunia. Sistem yang terlalu sentralistik dan tertutup di era Orde Baru langsung diubah menjadi sistem desentralisasi dan terbuka (Bachtiar, Menurunnya Kualitas Demokrasi, 2018). Menurut Pew Research Center, tahun 2017 terdapat 6 dari 10 negara di dunia merupakan negara demokrasi. Pada akhir 2016, 97 dari 167 atau 58\% negara di dunia berpenduduk 500.000 ke atas adalah negara demokrasi (Pew Research Center, 2007). 
Menurut Direktur Jenderal Informasi dan Diplomasi Publik Kementerian Luar Negeri Republik Indonesia Cecep Irawan, yang menyatakan bahwa tujuan dari suatu negara didirikan adalah untuk kesejahteran rakyat, dalam hal ini demokrasi dianggap sebagai satu sistem terbaik yang harus diterapkan dikawasan Asia-Pasifik maupun diluar kawasan, bahkan ada indeks yang menunjukan demokrasi tertinggi ada di Asia Pasifik (Ariesta, 2018).

\section{Demokrasi Sebagai Kebijakan Politik Luar Negeri Republik Indonesia}

Dinamika politik luar negeri Indonesia akan terus berubah menyesuaikan bentuk kepemimpinan Presiden dan isu-isu yang terjadi pada masanya. Pada masa kepemimpinan Susilo Bambang Yudhoyono, Indonesia harus dapat mengupayakan reformasi dari sistem otorkrasi ke sistem demokrasi. Dalam pandangan Indonesia, demokrasi perlu dikonsolidasikan dan berakar pada setiap aspek kehidupan nasional Indonesia, sebagaimana diabadikan dalam sistem nilai Pancasila, demokrasi sebagai falsafah bangsa, perlu diproyeksikan dalam kebijakan luar negeri Indonesia. Maka dari itu, mempromosikan demokrasi merupakan bagian integral dari kebijakan luar negeri Indonesia, khususnya di kawasan Asia.

Indonesia menekankan bagaimana demokrasi menjadi penting dan harus dibangun di kawasan berdasarkan pada prinsip utamanya yakni, demokrasi yang tidak dapat dipaksakan dari luar. Setiap perkembangan politik harus menjadi pengalaman 'tumbuh dari bawah'. Ini adalah sesuatu yang harus dibangun berdasarkan pengalaman sejarah dan kondisi budaya suatu negara, kemudain adalah sangat penting bagi komunitas bangsa di dunia, terlepas dari unsur ideologi dan kesetiaan poltik mereka, untuk belajar satu sama lain dalam menyempurnakan metode pemerintahan sehingga mereka dapat melayani tujuan kemakmuran dan kedamaian yang lebih baik. Proses saling belajar dan berbagi pengalaman akan semakin menentukan sifat demokrasi sebagai aktor pemersatu.

Fokus politik luar negeri Indonesia pada era Susilo Bambang Yudhoyono yaitu penerapan demokrasi domestik dengan slogan politik luar negerinya "Thousand Friend Zero Enemy". Slogan tersebut mempunyai tujuan Indonesia dalam menjalankan politik 
luar negerinya mencari teman sebanyak-banyaknya dan meminimalisir musuh. Dengan slogan tersebut tentunya sangat berpengaruh terhadap politik luar negeri yang akan membuka peluang kerjasama dan diplomasi di dunia internasional (Mashad, 2008). Selain itu Indonesia ingin memposisikan dirinya sebagai negara yang demokratis dan memiliki kepentingan nasional untuk memajukan kepemimpinan Indonesia dipanggung regional dan global melalui promosi demokrasi. Demokrasi juga menjadi fokus utama dalam dari politik luar negeri Indonesia, hal ini juga terlihat dari statemen Susilo Bambang Yudhoyono yang disampaikan dalam forum. SBY mempercayai bahwa demokrasi adalah elemen kunci dalam mempromosikan perdamaian dan stabilitas di kawasan. Banyak negara di kawasan yang menerima universalitas dari nilai-nilai demokrasi, seperti penghormatan terhadap HAM dan kebebasan fundamental, serta kepatuhan terhadapa nilai-nilai tersebut, hal ini dapat membantu mengkonsolidasikan perdamaian, stabilitas dan kemakmuran di kawasan (Tabloid Diplomasi, 2018).

\section{Strategi Diplomasi Publik Indonesia Dalam Mempromosikan Demokrasi Melalui}

\section{Bali Democracy Forum}

Dalam pelaksanaannya, diplomasi publik memerlukan strategi yang pada dasarnya terdapat pada tujuan politik luar negeri. Diplomasi publik digunakan untuk melengkapi upaya-upaya yang dilakukan oleh pemerintah yang dapat mengoptimalkan aktivitas komudpnikasi, yaitu dengan mengumpulkan, mengolah dan menyebarkan informasi demi kepentingan nasional sebuah negara. Indonesia melalui pelaksanaan Bali Democracy Forum telah menunjukkan bahwa pemerintah dapat mengumpulkan negaranegara yang hadir dalam forum untuk bisa saling berbagi pengalaman mengenai proses demokrasi pada masing-masing negara baik dikawasan Asia Pasifik maupun negara diluar kawasan.

\section{Kerjasama}

Capaian diplomasi publik Indonesia dalam mempromosikan dan mengembangkan nilai-nilai serta penerapan demokrasi dilakukan dengan beberapa cara, salah satunya yaitu melakukan kerjasama dengan institusi seperti: 


\section{Indonesia bekerjasama dengan Institute for Peace and Democracy (IPD)}

Institute for Peace and Democracy (IPD) terwujud atas prakarsa Presiden Susilo Bambang Yudhoyono yang telah diresmikan bersamaan dengan peresmian Bali Democracy Forum pada tahun 2008 untuk mengembangkan demokrasi. Institute for Peace and Democracy beranggotakan negara-negara di Asia Pasifik untuk memberikan kontribusi dalam mengembangkan dan mempromosikan demokrasi serta dapat dicermati sebagai bagian dari politik luar negeri Indonesia untuk membentuk institusi internasional (Sidauruk, 2015).Adapun tujuan pembentukan Institute of Peace and Democracy yakni (IPD.or.id, 2017):

- Memberikan dukungan substansi akademis dan teknis untuk dialog yang dilakukan Bali Democracy Forum.

- Mengelola dan mengorganisasi kegiatan regular dari Bali Democracy Forum dan bertindak sebagai lembaga yang mengimplementasikan agenda Bali Democracy Forum.

- $\quad$ Institute of Peace and Democracy menjadi pusat pengetahuan dan studi tentang demokrasi dan perdamaian.

- Mendorong pengembangan dan mempromosikan demokrasi di kawasan Asia Pasifik sebagai bagian dari peran politik luar negeri Indonesia (Sidauruk, 2015).

\section{Membentuk Forum Demokrasi}

Seperti yang sudah dijelaskan sebelumnya bahwa tujuan dibentuknya Bali Democracy Forum adalah untuk membangun serta mempertahankan sebuah forum antara negara-negara kawasan Asia Pasifik untuk mempromosikan pembangunan politik melalui dialog dan kerjasama dalam memperkuat nilai-nilai demokrasi. Untuk mencapai demokrasi yang inklusif dan komprehensif dari sudut yang beragam Kementerian Luar Negeri Indonesia melalui Bali Democracy Forum membentuk forum Bali Democracy Student Conference dan Bali Civil Society and Media Forum sebagai pengembangan 
dari Bali Democracy Forum. Forum tersebut dibentuk untuk dapat menyebarluaskan pemahaman demokrasi. Sasaran diplomasi publik yang ditujukan pada masyarakat luas dan juga media memberikan dampak yang besar bagi pelaksanaan forum tersebut. Berikut adalah forum pengembangan dari Bali Democracy Forum yang dilaksanakan di Nusa Dua, Bali:

\section{- $\quad$ Bali Democracy Student Conference (BDSC)}

Pada pelaksanaan Bali Democracy Forum 2018 mengadakan forum untuk para pelajar dengan tujuan agar pembahasan demokrasi dilakukan secara inklusif dan komprehensif dari sudut pandang yang beragam. Forum tersebut dinamai Bali Democracy Student Conference (BDSC). Menlu Retno Marsudi mengatakan dalam speechnya pada Bali Democracy Forum 2018 bahwa dunia memerlukan energi bagi para millenials untuk terus melanjutkan perjuangan dalam mempromosikan demokrasi. Pada Bali Democracy Student Conference (BDSC) dihadiri oleh 151 mahasiswa asing dari 61 negara yang hadir untuk saling berbagi pengalaman berdemokrasi di negaranya masing-masing. Para mahasiswa kemudian diajak untuk menyampaikan bagaimanakah demokrasi yang mampu tersampaikan dan bermanfaat terhadap masyarakat dalam kacamatanya masingmasing. Pada diskusi awal dipaparkan dari tiga narasumber muda yang berasal dari Amerika, Ethiopia dan Indonesia, yang menjelaskan bagaimana praktek sebuah demokrasi yang berhasil tersampaikan pada masyarakat.

Dalam forum ini ada begitu banyak perspektif yang disampaikan, mulai dari menceritakan bagaimana pengalaman demokrasi di negaranya ataupun demokrasi dan nilai-nilai yang seharusnya diangkat. Peran generasi muda dalam perkembangan demokrasi menjadi penting, karena mereka adalah agen perubahan dan perdamaian. Menerapkan nilai-nilai demokrasi dan budaya dialog akan menjauhkan generasi muda dari konflik. Melalui Bali Democracy Student Conference (BDSC), kaum millenial dapat mengetahui bahwa 
di era teknologi informasi saat ini merupakan sebuah peluang dan bukan ancaman bagi kehidupan masyarakat dimasa depan khususnya dalam hal berdemokrasi.

\section{- Bali Civil Society and Media Forum (BCSMF)}

BCSMF berfungsi sebagai jalan untuk berbagi pengalaman dan pembelajaran mengenai elemen-elemen demokratis dalam memajukan kesejahteraan. Kegiatan ini merupakan kegiatan parallel dari Bali Democracy Forum. Bali Civil Society and Media Forum (BCSMF) mengusung tema "Democracy Disfigured and the Prospect of Prosperity" dihadiri oleh 100 peserta dari 10 negara, yang terdiri dari Organisasi Masyarakat Sipil (CSO), Community of Democracy, Melanesian Spearhead Group, Pacific Islands Forum, dan cendikiawan. Delegasi Bali Civil Society and Media Forum (BCSMF) berpartisipasi di empat sesi, yakni Democracy Disfigured: Populism, Identity-Politics and Corruption, Public Sphere Captured: Hoaxes, Sensasionalism and Political Bias, The State, Regional and Global Changing Countours, dan Reconfiguring Democracy and the Prospects for Properity (Al-Aziz, 2018).

Bali Civil Society and Media Forum mendorong pembentukan narasi terkait demokrasi yang dapat dipahami oleh semua pihak sehingga dapat membantu mencegah polarisasi dan populisme yang dapat memicu konflik horizontal. Selain itu Bali Civil Society and Media Forum (BCSMF) juga mendorong dibentuknya institusi yang demokratis, penanaman demokrasi dalam mekanisme domestik, pembentukan lembaga think-tank serta mendorong kolaborasi inklusif untuk mendukung pembangunan berkelanjutan (SDGs). Dalam kolaborasi harus bersifat inklusif dan partisipatif dengan melibatkan pemerintah, akademisi, masyarakat sipil dan media, dan sektor swasta. 


\section{Pemanfaatan Media dalam Strategi Diplomasi Publik Indonesia}

Para pemimpin negara di kawasan Asia Pasifik yang tergabung dalam Bali Democracy Forum juga mengakui bahwa media sosial telah menjadi pelopor dalam pergerakan demokrasi di suatu negara. Media tidak hanya menjadi sumber berita, tetapi juga sekaligus merupakan pembawa dan penyambung suara rakyat. Media penting bagi demokrasi, media harus benarbenar dijaga independensinya, baik dari sisi lembaganya maupun dari insaninsan pers didalamnya. Kebebasan pers juga harus tetap dijaga dari adanya unsur intervensi dari lembaga kekuasaan dalam suatu negara (Djumena, 2010). Menurut Dirjen dan Diplomasi Publik Kementerian Luar Negeri A.M Fachir mengungkapkan media sosial kini dinilai telah menjadi pemicu meningkatnya peran masyarakat dalam demokrasi. Presiden Susilo Bambang Yudhoyono juga membuat statemen dengan meningatkan para pemimpin politik Indonesia agar selalu mendengarkan suara masyarakat yang disuarakan melalui media sosial, sebab media sosial selama ini telah memberikan peluang bagi masyarakat untuk menyampaikan berbagai aspirasinya sebagai bentuk implementasi demokrasi baik di Indonesia ataupun negara-negara di kawasan Asia Pasifik.

Terdapat beberapa media asing yang meliput jalannya forum Bali Democracy Forum ini sekaligus sebagai media dalam mempromosikan demokrasi, salah satunya yaitu adalah melalui media YouTube ABS-CBN News, yang merupakan YouTube Channel yang berasal dari negara Filipina.

\section{Peran Pelaksanaan Bali Democracy Forum (BDF) Terhadap Demokrasi di Asia Pasifik}

Capaian diplomasi publik Indonesia dalam mempromosikan demokrasi di kawasan Asia Pasifik dapat dikatakan berhasil, hal ini dilihat dari peningkatan jumlah peserta yang menghadiri Bali Democracy Forum smulai dari Bali Democracy Forum I sampai dengan XI. Negara di Asia Tenggara yang terkenal dengan junta militernya yakni Myanmar merasa 
bahwa Bali Democracy Forum ini membantu transisi demokrasi di Myanmar. Pengaruh Bali Democracy Forum tidak lepas dari tujuan dibentuknya forum tersebut adalah untuk menyebarkan demokrasi di Asia. Guna memajukan demokrasi di negaranya, Myanmar merasa kehadiran Bali Democracy Forum menjadi hal penting bagi Myanmar karena tema yang diusung menjadi tahapan penting bagi Myanmar untuk menyelesaikan permasalahan domestiknya. Bali Democracy Forum berperan sebagai forum yang mendorong Myanmar untuk menganut demokrasi melalui pendekatan regional.

Dalam kasus Rohingya, Indonesia mengecam keras atas perbuatan pemerintah Myanmar. Kasus ini akhirnya mengundang perhatian dari dunia internasional, sejumlah LSM Indonesia memberikan perhatian khusus untuk turut membantu etnis Rohingya. Namun Myanmar menolak bantuan dari luar dengan alasan tertentu, seperti LSM Perancis Medicins Sans Frontieres (MSF) saat sedang memberikan bantuan pelayanan kesehatan bagi pengungsi Rohingya. Alasan pemerintah Myanmar menghentikan LSM tersebut lantaran hanya memprioritaskan pasien Rohingya daripada pasien yang beragama Buddha seperti lebih memihak etnis Rohingya. Begitupun penolakan pemerintahan Myanmar terhadap PBB dengan alasan situasi keamanan yang belum kondusif (Maulana, 2017). Namun sebaliknya Myanmar menerima bantuan kemanusiaan dari Indonesia, seperti sejumlah LSM LSM Indonesia yaitu Aliansi Kemanusiaan Indonesia Myanmar (AKIM) yang beranggotakan sebelas Lembaga Swadaya Masyarakat di bidang kemanusiaan untuk satu tujuan membantu kemanusiaan di Myanmar. Dapat disimpulkan bahwa dengan keikutsertaan Myanmar pada Bali Democracy Forum setiap tahunnya memberikan dampak terhadap proses transisi demokrasi di Myanmar.

Negara Fiji adalah negara yang kerap hadir pada Bali Democracy Forum walaupun negara ini masih dalam proses menata demokrasi. Fiji mengalami beberapa kali pergantian pemerintahan dengan cara yang tidak 
demokratis seperti kudeta. Tercatat negara ini mengalami empat kali kudeta militer. Perilaku tersebut dianggap sebagai pelanggaran dari norma-norma demokrasi yang memunculkan berbagai perilaku negatif dari negara-negara lain (Moon, 2014). Pada tahun 2006 kudeta militer dilakukan terhadap Perdana Menteri Laisenia Qarase dan pembubaran seluruh konstitusi dengan melakukan kudeta oleh pimpinan militer Fiji Frank Bainimarama. Hingga pada akhirnya negara Fiji mencoba untuk mengakhiri budaya kudeta dengan mengadakan Pemilihan Umum (Pemilu).

Pemilihan ini akan menandai langkah maju yang penting untuk transisi negara itu menuju demokrasi. Duta Besar Wahid Supriyadi pemerintah Fiji mau mengikuti Bali Democracy Forum karena Fiji merasa terinspirasi untuk menata demokrasi di negaranya. Dalam hal ini penyelenggaraan Bali Democracy Forum berdampak serta memberikan pengaruh terhadap negara-negara yang masih dalam taraf memajukan demokrasi.

Selain Fiji, perkembangan demokrasi di Kamboja mendapat sorotan dunia karena demokrasi di Kamboja masih alami jatuh bangun. Negara ini masih kental dengan ideologi komunisme dan bentuk pemerintahan yang monarki. Namun tidak menutup kemungkinan Kamboja akan berkerjasama dengan Indonesia di bidang demokrasi. Menteri Luar Negeri Prak Sokhonn pada pertemuan Bali Democracy Forum ke-11 bahwa Kamboja terinsipirasi dengan kemajuan demokrasi Indonesia. Jika melirik sedikit ke belakang demokrasi di Kamboja masih sulit ditegakkan, seperti kasus Pelanggaran HAM, Perang Saudara hingga kecurangan dalam Pemilu di Kamboja menjadi pusat perhatian bagi dunia internasional (Medcom.id, 2018). Negara Tiongkok yang merupakan negara komunis dengan populasi terbesar di Asia dan pertumbuhan ekonominya yang menonjol, telah dan sedang mengalami transformasi ekonomi dan sosial untuk membuka dirinya bagi Asia dan dunia yang lebih luas. Pada Bali Democracy Forum pertama, Tiongkok hadir untuk 
turut serta belajar dan berbagi pengalaman mengenai penerapan dan nilai-nilai demokrasi. Ketika dilangsungkannya diskusi antar negara-negara yang hadir sebagai perwakilan, wakil Perdana Menteri Tiongkok Li Keqiang menyatakan akan bekerjasama dengan erat guna membangun pemahaman yang lebih besar dan mengejar nilai-nilai dasar dan universal yang umumnya diterima oleh komunitas internasional (Keqiang, 2008). Wakil Perdana Menteri Tiongkok juga menambahkan ada sebuah harapan besar bahwa Tiongkok akan terus membuat perkembangan sebagai sebuah kekuatan bertanggung jawab, dalam isu-isu tentang demokrasi dan hak asasi manusia bersama dengan isu-isu lainnya (Keqiang, 2008).

Sama seperti Kamboja, negara Vietnam juga merupakan negara yang masih kental ideologi komunisnya. Partai komunis yang berkuasa di Vietnam telah menekan kelompok-kelompok pro-demokrasi yang sedang berkembang dinegaranya. Kelompok pro-demokrasi dituduh akan menggulingkan pemerintah karena melakukan kegiatan subversiv melawan komunis yang berkuasa di Vietnam (Tempo.co, 2009). Para pemimpin Vietnam tidak terlalu tertarik pada hak-hak politik dan kebebasan individu yang didukung oleh negara Barat. Oleh karena itu demokrasi bagi mereka adalah ala Barat yang dikendalikan oleh kapitalis untuk negusai kepentingan ekonomi mereka. Vietnam juga tidak memiliki undang-undang yang menjelaskan tentang tata cara penegakan HAM. Dengan sistem politik Vietnam yang berbentuk sosialis, demokrasi dan HAM masih jauh dari kenyataan di negara ini (Sinaga, 2013). Namun tidak menutup kemungkinan bahwa Vietnam hadir pada penyelenggaraan Bali Democracy Forum Vietnam. Parlemen Vietnam Ketua Majelis Nasional Nguyen Thi Kim Ngan mengungkapkan bahwa keikutsertaannya dalam Bali Democracy Forum diharapkan dapat membawa perubahan bagi negara Vietnam, meskipun forum Bali Democracy Forum merupakan forum untuk bertukar pikiran, sharing experience mengenai 
pelaksanaan nilai-niali demokrasi pada masing-masing negara yang hadir (Sinaga, 2013).

Melalui demokrasi akan tercipta masyarakat madani yang terbuka bagi diskusi, komunikasi dan saling pengertian guna mengatasi berbagai potensi konflik. ketika Indonesia mampu memposisikan diri sebagai garda terdepan dari pembangunan demokrasi, pembangunan demokrasi sangat penting bagi Indonesia dan masyarakat dunia, terlepas dari ideologi dan aliran politik mereka, untuk belajar satu sama lain dalam menyempurnakan metode pemerintahan sehingga dapat lebih mencapai kemakmuran dan persamaian. Proses saling belajar dan berbagi pengalaman akan menjadi sifat demokrasi sebagai alat pemersatu (m.liputan6.com, 2013). Maka akan tercipta frame bahwa stabilitas politik Indonesia berada pada posisi yang baik. Pelaksanaan Bali Democracy Forum tentu memberikan manfaat tersendiri bagi Indonesia. Beberapa manfaat tersebut yakni:

1. Meningkatkan peran serta kepemimpinan Indonesia dalam kerjasama antar negara-negara anggota dan kawasan Asia Pasifik dibidang politik-keamanan, ekonomi dan sosial-budaya.

2. Meningkatkan dukungan masyarakat internasional, khususnya dari negara-negara anggota ASEAN terhadap keutuhan dan kedaulatan RI.

3. Meningkatkan hubungan bilateral dan multilateral yang saling menguntungkan.

4. Meningkatkan dukungan dan kepercayaan masyarakat internasional terhadap Indonesia yang dmeokratis, aman, damai, adil, dan sejahtera.

Dengan demikian, pemerintah kiranya perlu memperhatikan dinamika dan interaksi tidak hanya pada level politik internasionalsaja tetapi juga mnegenai isu domestik. Hal ini dikarenakan dalam kebijkan luar negeri sebagai bagian yang langsung maupun tidak langsung timbul dan terkait erat 
dengan permasalahan dalam kebijakan dalam negeri, seperti yang tercermin dari masalah perbatasan, lingkungan, budaya, lemahnya penegakan hukum, maupun keamanan sehingga penting bagi Indonesia untuk terus memperhatikan isu-isu domestik yang membutuhkan penangangan bersama para naggota dan dunia internasional (m.liputan6.com, 2013)

\section{KESIMPULAN}

Bali Democracy Forum merupakan forum tahunan antarpemerintah yang bersifat inklusif dan terbuka. Forum ini di gagas oleh Presiden Susilo Bambang Yudhoyono pada tahun 2008 dengan tujuan untuk mempromosikan demokrasi dan memajukan proses demokrasi di kawasan Asia Pasifik. Sebagai bagian integral dari kebijkan luar negeri, Indonesia berhasil menunjukan bagaimana demokrasi harus dibangun berdasarkan prinsip-prinsip utama, yaitu demokrasi yang tidak dipaksakan dari luar dan setiap perkembangan politik harus menjadi dasar pengalaman sejarah bangsa sendiri dan kondisi budaya. Selain itu. Indonesia dalam mempromosikan demokrasi juga merupakan bagian dari kebijakan politik luar negeri era Susilo Bambang Yudhoyono. Melihat situasi di kawasan Asia Pasifik yang masih setengah hati dalam pelaksanaan demokrasi di masing-masing negara.

Inisiasi Bali Democracy Forum yang dibentuk Presiden Susilo Bambang Yudhoyono dapat dikatakan berhasil, hal ini terlihat dari peningkatan peserta Bali Democracy Forum yang terus mengalami peningkatan setiap tahunnya. Negara-negara yang juga mengikuti forum tersebut dikatakan mampu menjalankan demokrasi dengan baik, hal ini terlihat dari perubahan pada indeks demokrasi tahun 2007 sampai 2018.

Demokrasi Indonesia mampu berkembang dengan memiliki corak yang khas, berdasarkan pada nilai-nilai lokal dan begitu juga demokrasi di negara-negara lain sehingga perlu sebuah forum kerjasama antar negara di Asia Pasifik untuk mempromosikan parktek demokrasi yang berdasar pada kearifan lokal.

\section{DAFTAR PUSTAKA BUKU:}

Bakry, U. S. (2016). Metode Penelitian Hubungan Internasional. Pustaka Pelajar. Yogyakarta. 
Bruce Martin Russet, H. S. (1988). World Politics: The Menu for Choice. W.H Freeman and Co. New York.

D William, C. d. (1992). Pengantar Politik Internasional. CV. Sinar Baru. Bandung.

Gramae, G. (2003). Liberalization and Democratization in the Union and Russia.

Huda, N. (2010). Hukum Tata Negara Indonesia. Rajawali Pers. Yogyakarta.

Kelsen, H. (2006). Teori Umum Tentang Hukum dan Negara. Nuansa dan Penerbit Nusamedia. Bandung.

Manan, M. (2005). Gerakan Rakyat Melawan Elite. Resist Book. Yogyakarta.

Margaretha. (2014). Diplomasi. PT Gramedia. Bandung.

Mashad, D. (2008). Politik Luar Negeri Indonesia Era Reformasi. Pustaka Pelajar. Jakarta.

Mas'ud, M. (1994). Ilmu Hubungan Internasional: Disiplin dan Metodologi. LP3ES. Jakarta.

Moleong, L. J. (2007). Metodologi Penelitian Kualitatif. PT Remaja Rosdakarya. Bandung.

Nimmo, D. (2006). Komunikasi Politik Khalayak dan Efek. PT Remaja Rosdakarya. Bandung.

Porter, G. (2008). Indonesia After Reformation : The Prospect of Liberation and Democracy. Vintage Publishing. New York.

Rana, K. S. (2011). 21 st Century Democracy. The Continuum Publishing. London.

Rezasyah, T. (2014). Transisi Penerapan Regulasi Baru di Hong Kong. CNN Indonesia.

Rosenau, J. N. (1976). World Politics: An Introduction. The Free Press. New York.

Rosenau, J. N. (1980). The Scientific Study of Foreign Policy. The Free Press. New York.

Roy, S. (2006). Diplomasi. PT Grafindo Persada. Jakarta.

Sukardi. (2004). Metodologi Penelitian Pendidikan. Bumi Aksara. Jakarta.

Tutik, T. T. (2010). Konstruksi Hukum Tata Negara Indonesia Pasca Amandemen UUD 1945. Kencana Predana Media Group. Jakarta.

Walliman, N. (2011). Reasearch Methods: The Basic. Routledge. New York. 